\title{
ISLAM, TRADISI LOKAL, DAN KONSERVASI ALAM: Studi Kasus di Kampung Dukuh Kabupaten Garut
}

\author{
Abdul Syukur \& Husnul Qodim \\ UIN SunanGunung Djati Bandung \\ abdul_syukur05@yahoo.com \& husnulqodim@uinsgd.ac.id
}

\begin{abstract}
Abstrak
Kampung Dukuh di Kecamatan Cikelet, Kabupaten Garut merupakan salah satu kampung adat yang ada di Jawa Barat. Selain tradisi warisan Islam yang masih kuat, masyarakat Kampung ini mempunyai tradisi tersendiri seperti kepercayaan terhadap mitos-mitos leluhur, sanksi gaib, dan ritual-ritual tertentu terkait kepercayaan tersebut. Masyarakat Kampung Dukuh juga memiliki kearifan lokal yang berkaitan dengan pelestarian lingkungan dan sumber daya alam lewat mana mereka turut serta dalam menghadapi isu-isu pemanasan global (global warming) dan perubahan iklim (climate change). Keberhasilan warga Kampung Dukuh dalam melestarikan alam bukan karena pengaruh doktrin Islam tetapi lebih disebabkan oleh tradisi dan kearifan lokal warisan nenek moyang. Hal ini dikarenakan masyarakat Kampung Dukuh cenderung memahami Islam sebagai seperangkat aturan/hukum berkaitan dengan sistem peribadatan (fiqih ibadah), tidak sampai menyentuh aspek-aspek lain di luar sistem itu.
\end{abstract}

Abstract

Kampung Dukuh, in Cikelet District of Garut regency is one of the traditional villages in West Java. Beside the tradition of Islamic heritage ehich is still strong, the villagers possess their own 
tradition, such as : the belief in the ancestors' myths, supernatural sanctions, and certain rituals related to these beliefs. The Kampung Dukuh community also possess local wisdoms relating to the preservation of the environment and natural resources by which they participate in facing with the issues of global warming and climate changes. The success of Kampung Dukuh in preserving nature is not due to the influences of Islamic doctrine, rather due to the their indigenous heritage. This is because the people of Kampung Dukuh tend to understand Islam as rules of worship, not to touch other aspects outside of the regulation.

Key Word: Masyarakat Tradisional, Islam, local wisdom, Konservasi Alam.

\section{A. Pendahuluan}

Masalah lingkungan hidup telah menjadi perhatian dunia secara glogal disebabkan oleh berbagai kerusakan lingkungan yang terjadi di berbagai negara maju maupun berkembang. Di negara-negara maju masalah lingkungan pada umumnya disebabkan oleh berbagai kegiatan industri modern, sedangkan di Indonesia kerusakan lingkungan umumnya disebabkan oleh dampak negatif kemiskinan, juga oleh kegiatan industri. Dampak kerusakan lingkungan ini antara lain terjadinya kerusakan hutan, erosi tanah, kepunahan satwa liar (fauna), kepunahan tumbuh-tumbuhan (flora), penurunan stok ikan dan udang, serta pencemaran limbah rumah tangga dan pabrik.

Kerusakan lingkungan hidup di Indonesia terjadi di berbagai tempat dan tipe ekosistem. Kerusakan lingkungan pada ekosistem pertanian, misalnya, terjadi pada sawah maupun lahan kering non-sawah. Introduksi varietas padi unggul pada masa Orde Baru serta penggunaan pupuk kimia dan pestisida yang tak terkendali, di satu sisi, telah berjasa meningkatkan produksi padi secara nasional. Namun, di sisi lain, program tersebut telah menyebabkan kerusakan lingkungan hidup yang tidak sedikit. Pupuk kimia dan pestisida yang masuk ke badan perairan seperti sungai, kolam, 
Islam, Tradisi Lokal, dan Konservasi Alam:

dan danau telah mengganggu lingkungan perairan dan menyebabkan pencemaran air, pendangkalan sungai, danau, sehingga mengganggu kehidupan ikan, udang, dan satwa air lainnya.

Kerusakan ekosistem di laut, misalnya, adalah berkurangnya keaneka-ragaman fauna di hutan bakau (mangrove) dan terganggunya habitat satwa liar seperti burungburung dan mamalia. Ini terjadi karena banyak hutan bakau yang ditebang untuk dijadikan kayu bakar, bahan bangunan, arang, tonggak-tonggak bagan, serta tempat memasang jaring ikan. Selain itu, hutan bakau juga dibuka untuk dijadikan daerah pemukiman, perkebunan, serta pertambakan udang dan bandeng. Sedangkan kerusakan ekosistem hutan terjadi akibat pembukaan lahan gambut secara besar-besaran, pencurian hasil hutan, serta pembukaan hutan untuk lahan perkebunan maupun proyek transmigrasi, sehingga keanekaragaman flora dan fauna hutan menurun drastis serta manfaat hutan bagi manusia pun terganggu. ${ }^{1}$

Kampung Dukuh adalah salah satu kampung adat di Jawa Barat, tepatnya berada di Desa Ciroyom Kecamatan Cikelet Kabupaten Garut. Sebelumnya, Kampung Dukuh termasuk ke dalam wilayah Desa Cijambe, namun dengan terjadinya pemekaran Desa Cijambe menjadi Desa Cijambe dan Desa Ciroyom maka kini Kampung Dukuh menjadi bagian dari wilayah administrasi Desa Ciroyom.

Kampung Dukuh terdiri dari kawasan pemukiman seluas kurang lebih 7 ha, Hutan Larangan (Hutan Keramat) dan Hutan Titipan (Tutupan) seluas kurang lebih 10 ha, perkebunan, dan sawah. Di dalam Hutan Larangan terdapat area yang disebut dengan wilayah Karomah, tempat di mana Syekh Abdul Jalil yang dianggap sebagai karuhun (asal-usul

${ }^{1}$ Iskandar, Manusia Budaya dan Lingkungan: Ekologi Manusia, (Bandung: Humaniora Utama Press, 2001) h. 1-6. 
atau nenek moyang) tokoh sekaligus sebagai pendiri penduduk Kampung Dukuh, dimakamkan.

Sebagaimana kampung-kampung adat yang lain, di Kampung Dukuh terdapat Hutan Larangan (Hutan Keramat) yang tidak boleh diganggu oleh penduduk setempat maupun orang lain yang datang berkunjung. Adanya larangan untuk mengambil kayu atau bahkan ranting yang telah lapuk sekalipun dari dalam Hutan Larangan ini memberikan dampak positif pada pelestarian tumbuh-tumbuhan baik yang ada di dalam hutan maupun di sekitarnya. Para ahli lingkungan seringkali mengidentifikasi adat dan tradisi masyarakat adat dengan istilah kearifan lokal (local wisdom) dan menghubungkan kearifan lokal yang berisi macam-macam larangan tersebut dengan upaya pelestarian alam (natural conservation) dan keaneka-ragaman hayati (flora dan fauna) serta tata kelola air (hidrologi). ${ }^{2}$

Selain itu, semua penduduk Kampung Dukuh mengaku sebagai orang Sunda. Hal ini nampak pada cara ereka berkomunikasi yaitu menggunakan bahasa Sunda dan dalam hal berpakaian mereka menggunakan pakaian adat Sunda, seperti pangsi hitam dengan ikat di kepala.

Di samping menjadi pewaris tradisi kebudayaan Sunda warisan nenek moyang, tradisi ke-Islam-an di Kampung Dukuh juga nampak jelas. ${ }^{3}$ Di Kampung Dukuh, misalnya, terdapat masjid dan madrasah, yaitu di Kampung Dukuh Dalam. Baik masjid maupun madrasah masih berfungsi sebagaimana mestinya. Masjid dipergunakan oleh penduduk Kampung Dukuh untuk shalat berjamaah lima waktu, termasuk shalat Jumat di mana Kuncen biasa memberikan khutbah. Sedangkan

\footnotetext{
${ }^{2}$ Lihat, misalnya, 'Kampung Kuta: Sebuah Dunia Tanpa Perniagaan' dalam Zerorisk, vol. 07, September-Oktober 2013.

${ }^{3}$ Masalah hubungan antara Islam dan Sunda sebagai identitas etnik dibicarakan oleh Abdul Syukurdalam 'Islam, Etnisitas dan Politik Identitas: Kasus Sunda',(Miqot: Jurnal Ilmu-ilmu Keislaman), vol. XXXV No 2 Juli-Desember 2011.
} 
Islam, Tradisi Lokal, dan Konservasi Alam:

madrasah terdiri dari 2 lantai yang digunakan baik untuk belajar ngaji anak-anak maupun pengajian ibu-ibu.

Masjid yang terdapat di Kampung Dukuh Dalam berukuran $10 \times 12$ meter. Di pinggir masjid terdapat bedug besar yang terbuat dari kayu pohon Binong. Kayu tersebut dilubangi tengahnya sehingga berbentuk lingkaran tanpa sambungan. Kemudian, kedua lubang sisinya ditutup dengan kulit sapi yang dipaku pada lingkaran kayu bedug tersebut. Bedug ini berfungsi untuk memberi tahu waktu shalat dengan cara dipukul secara berirama.

Tulisan ini berusaha untuk menelusuri hubungan antara konservasi alam (natural conservation) yang dilakukan masyarakat Kampung Dukuh dengan nilai-nilai dan praktikpraktik keagamaan warga Kampung Dukuh dan kearifan lokalnya. Pertanyaannya adalah apakah konservasi alam di Kampung Dukuh tersebut dilandasi nilai-nilai agama Islam yang menjadi keyakinan mereka dan merupakan hasil praktik keagamaan tersebut atau, seperti kampung-kampung adat lainnya, merupakan buah dari ketaatan mereka terhadap adat dan tradisi warisan nenek moyang yang telah melembaga?

Penelitian dilakukan dengan menggunakan metode etnografi. Peneliti tinggal bersama masyarakat Kampung Dukuh, melakukan observasi terhadap keadaan sekitar dan apa yang dilakukan warga Kampung Dukuh serta menanyakan maksud dan arti dari setiap hal yang disaksikan. Setelah itu, dilakukan pengolahan atau analisis data dengan merangkai hubungan-hubungan yang mungkin antara berbagai informasi yang diperoleh.

\section{B. Asal-usul dan Kehidupan di Kampung Dukuh}

Kampung Dukuh berada pada ketinggian 400 meter di atas permukaan laut (dpl) dan berjarak $8 \mathrm{~km}$ dari jalan raya Pameungpeuk - Cikelet dengan menembus hutan jati milik Perhutani. Tidak ada angkutan umum reguler yang 
menghubungkan Kampung Dukuh dengan daerah lainnya kecuali ojek motor dan dua buah mobil mikrobus menuju Bandung pergi-pulang yang berangkat dan datang hanya pada waktu-waktu tertentu. Sebenarnya, apabila jalan mulus maka jarak tersebut dapat ditempuh selama seperempat jam saja. Akan tetapi, dengan kondisi jalan bebatuan yang tidak rata membuat kendaraan harus merayap menempuh jalan menanjak dengan memilih-milih arah jalan yang akan dilalui. Dengan medan yang sedemikian sulit maka perjalanan untuk mencapai Kampung Dukuh dari jalan raya harus ditempuh selama satu jam dengan menggunakan mobil pribadi atau setengah jam dengan kendaraan sepeda motor. Apalagi pada musim penghujan di mana jalan menjadi licin sehingga pengemudi harus ekstra hati-hati.

Kampung Dukuh terletak di lembah dengan batas-batas Sungai Cimangke di sebelah timur dan Sungai Cisarangan di sebelah barat; di sebelah utara berbatasan dengan Hutan Tutupan dan Hutan Titipan yang di dalamnya terdapat makam keramat Syekh Abdul Jalil, sedangkan di sebelah selatan berbatasan dengan hutan jati milik Perhutani.

Kampung Dukuh, terdiri dari 3 Rukun Tetangga (RT) yang membentuk satu Rukun Warga (RW) yaitu RW 6, masuk ke dalam wilayah administrasi Desa Ciroyom Kecamatan Cikelet Kabupaten Garut. Berdasarkan data dari Profil Desa Ciroyom Tahun 2015 jumlah penduduk Kampung Dukuh adalah 588 orang dengan hampir setengahnya (215 orang) berada pada usia produktif (26- 64 tahun).

Kampung Dukuh terdiri dari dua bagian, yaitu Dukuh Luar atau Dukuh Landeuh (landeuh = bawah) dan Dukuh Dalam atau Dukuh Tonggoh (tonggoh $=$ atas). Berdasarkan fungsi Kampung Dukuh sebenarnya terbagi atas tiga bagian, yaitu Dukuh Dalam, Dukuh Luar, dan Taneuh Karomah (Tanah Keramat). Antara bagian yang satu dengan bagian lainnya di batasi oleh pagar tanaman. Apabila di dalam Dukuh Dalam 
Islam, Tradisi Lokal, dan Konservasi Alam:

dan Dukuh Luar terdapat rumah-rumah adat yang ditempati penduduk Kampung Dukuh, maka di dalam Taneuh Karomah (Tanah Keramat) terdapat Makom Karomah (Makam Keramat). Itu sebabnya wilayah tersebut disebut Taneuh Karomah (Tanah Keramat).

Menurut cerita, Kampung Dukuh didirikan oleh seorang tokoh yang bernama Syekh Abdul Jalil. Beliau adalah seorang ulama yang diminta oleh Bupati Sumedang, Rangga Gempol II, untuk menjadi Penghulu (kepala agama) di kerajaan Sumedang pada abad XVII Masehi. Sebelum memberikan persetujuannya Syekh Abdul Jalil mengajukan 2 syarat kepada Rangga Gempol. Pertama, Rangga Gempol II tidak boleh melanggar hukum syara (hukum agama), seperti membunuh, berzinah, merampok, dan sebagainya; Kedua, Rangga Gempol II sebagai bupati/pemimpin harus bersatu dengan rakyat. Kedua persyaratan diterima Rangga gempol, maka Syekh Abdul Jalil pun diangkat menjadi Penghulu di Kerajaan Sumedang.

Akan tetapi, ketika melaksanakan ibadah haji di Mekah Syekh Abdul Jalil mendengar berita bahwa di Kerajaan Sumedang telah terjadi pembunuhan terhadap utusan dari Banten yang meminta agar Sumedang tidak tunduk dan memberi upeti kepada Kerajaan Mataram. Mendengar berita tersebut maka sepulang dari menunaikan ibadah haji Syekh Abdul Jalil pun mengundurkan diri dari jabatnnya dan pergi meninggalkan Kerajaan Sumedang. Ia mula-mula pergi ke Batuwangi dan tinggal di sana beberapa lama, kemudian melanjutkan perjalanannya ke arah selatan sehingga sampai di suatu daerah yang bernama Tonjong yang terletak di sisi sungai Cisanggiri.

Pada suatu hari, saat Syekh Abdul Jalil bertafakur, beliau melihat sebuah sinar di langit bergerak menuju ke suatu arah tertentu. Pergerakan sinar tersebut kemudian diikuti oleh Syekh Abdul Jalil dan kemudian berhenti di suatu daerah di antara sungai Cimangke dan Cipasarangan. Daerah tersebut 
ternyata telah dihuni oleh sepasang kakek-nenek bernama Candradiwangsa. Setelah kedatangan Syekh Abdul Jalil ke tempat tersebut maka kakek dan nenek Candradiwangsa pun menyerahkan daerah tersebut kepada Syekh Abdul Jalil. Syekh Abdul Jalil pun akhirnya menetap di sana sambil menyebarkan agama Islam ke daerah sekitarnya. ${ }^{4}$ Maka terbentuklah sebuah kampung yang saat ini dikenal dengan nama Kampung Dukuh.

Mata pencaharian utama masyarakat Kampung Dukuh adalah pertanian. Sistem pertanian yang dilakukan masyarakat Kampung Dukuh adalah menanam padi di lahan basah (sawah)

${ }^{4}$ Tidak ada data historis berkenaan dengan proses Islamisasi di wilayah Garut Selatan kecuali berdasarkan cerita rakyat (folklore).Dalam buku Dongengdongeng Pakidulan Garut yang dikeluarkan oleh Dinas Pariwisata dan Kebudayaan Kabupaten Garut, misalnya, dapat disimpulkan bahwa proses Islamisasi yang terjadi di daerah Garut Selatan terjadi melalui dua cara, yaitu dengan cara mengajak (dakwah) dan jalan memperlihatkan kesaktian (adu jajaten).Cara yang pertamaseperti yang dilakukan oleh Asdar atau yang kemudian disebut sebagai Eyang Caladi, seorang keturunan Maulana Hasanuddin, Sultan di Kerajaan Banten, yang berdakwah di kalanganmasyarakat Pamalayan yang masih beragama Buddha.Sayangnya, ajakan Asdar tersebut tidak mendapat sambutandan kehadiran Asdar ditolak sehingga mereka pun tetap dalam keadaan beragama Buddha.Cara penyebaran Islam dengan jalan mengajak juga diperlihatkan oleh Keyan Santang, salah seorang anak Prabu Siliwangi dari Nyi Mas Subang Larang dari Karawang yang telah beragama Islam. Akan tetapi, Prabu Siliwangi yang beragama Hindu berusaha menolak dengan halus ajakan anaknya tersebut dan Prabu Siliwangi pun akhirnya meninggalkan keraton dan menjadikan keraton tersebut hutan belantara. Proses penyebaran Islam dengan cara yang kedua dilakukan oleh Syekh Abdul Jalil.Diceritakan bahwa Syekh Abdul Jalil dari Pameungpeuk bermaksud menemui Kanjeng Dalem di Sukapura, ibukota kabupaten, dengan membawa bekal batang daun kawung yang dapat mengeluarkan air nira. Di tengah perjalanan ia dihadang oleh sekawanan begal yang dipimpin oleh Ki Entol Jawiria dan Ki Bungsuyang berusaha merampas bekal Syekh Abdul Jalil. Syekh Abdul Jalil melemparkan batu dan kawanan begal pun berlari dan berlomba memperebutkan batu yang dilempar Syekh Abdul Jalil. Syekh Abdu Jalil pun terus berlalu.Ketika Syekh Abdu Jalil pulang melalui jalan yang sama ia mendapati kawanan begal tersebut masih berkelahi memperebutkan batu hingga kelelahan. Akhirnya para begal pun minta ampun kepada Syekh Abdul Jalil. Syekh Abdul Jalil memberi ampun dan memerintah mereka untuk masuk dan menyebarkan agama Islam di sekitar Cikelet. 
Islam, Tradisi Lokal, dan Konservasi Alam:

dan di lahan kering (huma atau berladang). Sistem huma berbeda dengan sawah. Apabila sawah dapat menghasilkan padi dua kali dalam satu tahun maka huma hanya sekali (masa tanam padi huma antara 4-5 bulan); apabila pengairan sawah berdasarkan kepada sistem irigasi maka tanaman padi huma bergantung kepada hujan. Oleh karena itu, padi huma biasanya ditanam pada awal musim penghujan. Selain menanam padi huma di kawasan hutan Perhutani penduduk juga menanam padi huma di tanah-tanah milik mereka sendiri, terutama tanah yang terletak di tempat-tempat yang tinggi yang tidak terjangkau oleh aliran air irigasi.

Selain bertani penduduk Kampung Dukuh juga berkebun dan memelihara ternak. Hampir semua penduduk Kampung Dukuh menanami kebun mereka dengan bermacam-macam pohon dan buah-buahan. Hasil kebun penduduk berupa kayukayu hutan, seperti bambu, kayu kihiyang dan pohon kelapa, sedangkan hasil buah-buahan terdiri dari rambutan, durian, pisang, mangga, jambu, dan lain-lain. Termasuk hasil kebun adalah ketela, sukun, cengkeh, petai, gula aren, dan lain-lain. Kebanyakan hasil kebun ini dijual ke pasar tetapi ada juga yang dikonsumsi langsung, dan beberapa hasil kebun yang tidak dijual dibuat bermacam-macam penganan seperti apem, raginang, wajit, kripik sukun, kripik pisang, kripik ketela, dan lain-lain.

Sementara itu, untuk mencukupi protein hewani penduduk Kampung Dukuh memelihara ternak dan ikan. Hampir setiap rumah memiliki kolam yang di atasnya terdapat jamban (tempat mandi dan WC). Di dalam kolam tersebut mereka memelihara ikan seperti ikan mas, jaer, dan nila. Ikan-ikan tersebut selain mendapat makanan dari kotoran manusia juga diberi pakan sisa-sisa makanan dari dapur. Sedangkan ternak yang dipelihara terdiri dari ayam, kambing, dan sapi. Kandang ayam berada di bawah rumah (panggung) dan kandang kambing dibuat di belakang rumah, sedangkan 
untuk kandang sapi dan kerbau harus dibuat di luar Kampung Dukuh. Ketentuan ini disebabkan areal Kampung Dukuh yang sangat terbatas dan tidak memungkinkan untuk ditambahi dengan kandang kerbau atau sapi. Kotoran dari hewan-hewan inilah yang kemudian dimanfaatkan untuk pupuk padi huma maupun tumbuh-tumbuhan di kebun sebagai pupuk organik. Itu sebabnya, demikian dikatakan Husen, kualitas padi huma dan hasil kebun penduduk Kampung Dukuh khususnya termasuk sangat baik (harum) dan enak ketika dimakan.

\section{Kampung Dukuh sebagai Kampung Adat}

Sebagai Kampung Adat di Kampung Dukuh terdapat banyak larangan yang harus dipatuhi oleh penduduknya. Misalnya, di rumah-rumah penduduk di Kampung Dukuh tidak boleh menggunakan listrik. Rumah juga harus berbentuk panggung, berdinding papan kayu atau bilik dari anyaman bambu, dan beratap rumbai ijuk atau ilalang. Pintu rumah harus menghadap ke timur dan barat, dan jendela tidak boleh menggunakan kaca. Begitu juga, dalam kehidupan seharihari terdapat berbagai macam larangan yang disebut dengan pamali. Pemberitahuan tanda masuk waktu shalat dilakukan dengan menggunakan bedug yang dipukul selain karena di Kampung Dukuh dilarang menggunakan pengeras suara juga karena pengeras suara hanya berfungsi apabila ada aliran listrik sebagai sumbernya.

Kampung Dukuh terdiri dari dua bagian: Dukuh Luar dan Dukuh Dalam. Rumah adat yang terdapat di kawasan Kampung Dukuh Dalam, yang menjadi pusat tradisi dan rumah kuncen berada, sebelumnya berjumlah 40 buah. Akan tetapi, jumlah rumah tersebut sekarang tinggal 38 buah, termasuk bangunan masjid, Bale Adat, Madrasah, Bumi Alit, dan tempat mandi Cebor Opat Puluh. Dua rumah adat dibongkar karena orangnya pindah dan membuat rumah di luar. Rumah Kuncen (Mama 
Islam, Tradisi Lokal, dan Konservasi Alam:

Uluk) sendiri lebih besar dibandingkan dengan rumah-rumah penduduk lainnya, karena Kuncen biasa menerima tamu.

Selain Dukuh Dalam, Dukuh Luar, dan Tanah Keramat, terdapat juga beberapa bidang tanah dengan rincian luas yang kurang jelas, yang disebut awisan. Awisan berarti cadangan; pengertian awisan terdapat dalam uga (wasiat leluhur) yang berbunyi "di daerah itu akan datang orang-orang dari daerah Sumedang, Bengkelung, Arab, Sukapura, dan dari Kampung Dukuh sendiri." Tanah awisan disebut sesuai dengan nama daerahnya yaitu Awisan Sumedang, Awisan Arab, Awisan Sukapura, dan Awisan Dukuh. Awisan Sumedang di sebelah timur, Awisan Arab dan Awisan Sukapura di sebelah barat, sedangkan Awisan Dukuh di sekeliling kampung. Tidak ada tanah awisan di sebelah utara karena di bagian tersebut terletak Makam Keramat.

Tanah dan rumah-rumah yang berada pada kawasan Kampung Dukuh Dalam dinyatakan pemerintah sebagai Cagar Budaya dan, oleh karena itu, tidak dikenai Pajak Bumi dan Bangunan (PBB), sedangkan tanah-tanah dan rumah-rumah penduduk yang berada di kawasan Kampung Dukuh Luar merupakan hak milik sehingga pemerintah memberlakukan penarikan Pajak Bumi dan Bangunan (PBB) dari penduduk tersebut.

Bentuk rumah adat tersebut adalah rumah panggung beratap rumbia dengan arah atap membujur dari timur ke barat; pintu rumah berada di kedua sisi timur dan barat; dinding masih terbuat dari bilik (anyaman bambu) atau papan; pintu serta jendela dan lantai terbuat dari papan kayu; sedangkan pada malam hari digunakan penerangan lampu minyak tanah.

Tidak sedikit di antara penduduk Kampung Dukuh Luar maupun Dalam yang memiliki kendaraan sepeda motor sebagai alat transportasi, hanya saja kendaraan motor tersebut tidak diperkenankan memasuki kawasan Kampung Dukuh Dalam. 
Oleh karena itu, mereka yang tinggal di Kampung Dukuh Dalam harus menyimpan kendaraan mereka di area Kampung Dukuh Luar. Begitu pun penduduk di kawasan Kampung Dukuh Dalam tidak diperbolehkan membuka warung, mereka yang hendak usaha berdagang dengan membuka warung harus melakukannya di luar Kampung Dukuh Dalam.

Sementara penduduk di Kampung Dukuh Dalam masih tetap mempertahankan adat atau tradisi dengan ketat. Penduduk yang tinggal di Kampung Dukuh Luar telah mengalami beberapa perubahan. Misalnya, atap rumah di Kampung Dukuh Luar diperbolehkan menggunakan atap dari genting, begitu juga mereka diperbolehkan menggunakan lampu penerangan listrik. Bahkan, beberapa rumah di Kampung Dukuh Luar telah menggunakan antena parabola untuk menangkap siaran televisi. Meskipun demikian dalam hal-hal tertentu mereka masih mempertahankan ketentuan adat, seperti rumah tetap berbentuk panggung dan arah atap rumah tetap membujur dari timur ke barat, dan pintu rumah berada di kedua sisi timur dan barat. Begitu juga dinding masih terbuat dari bilik (anyaman bambu) atau papan dan pintu serta jendela dan lantai terbuat dari papan kayu.

\section{Larangan dan Ritual Adat}

Kuncen Kampung Dukuh adalah keturunan Syeikh Abdul Jalil, tokoh yang dianggap sebagai cikal-bakal penduduk Kampung Dukuh. Seluruh kebijakan yang berkaitan dengan kehidupan penduduk Kampung Dukuh, termasuk dalam pengaturan dan penerapan hukum adat, berada di tangan kuncen.

Kuncen di Kampung Dukuh mempunyai kedudukan lebih dari sekedar penjaga Makam Keramat. Sebagai pemimpin masyarakat secara adat, kuncen juga sekaligus sebagai pelindung tradisi warisan nenek moyang. Sebagai pelindung adat, kuncen dianggap dapat mewakili masyarakat Kampung 
Islam, Tradisi Lokal, dan Konservasi Alam:

Dukuh untuk berhubungan dengan nenek moyang. Sebaliknya, pesan yang ingin disampaikan leluhur dapat diterima oleh kuncen melalui firasat yang dirasakan pada waktu maneja (meditasi), lewat mimpi, atau gejala-gejala alam yang kemudian ditafsirkan oleh kuncen. Agar tetap dapat berhubungan dengan nenek moyang maka kuncen harus selalu memelihara "kesuciannya" dengan melaksanakan beberapa ketentuan di antaranya harus memakai kain sarung dan tidak boleh memakai pakaian dalam; harus memakai baju kampret (koko), dan ikat kepala berwarna hitam atau biru. Selain itu, kuncen juga harus makan beralaskan jahas (piring kayu) dan minum dari bekong (cangkir batu atau batok kelapa) serta dilarang memakai alat-alat yang terbuat dari gelas atau logam.

Di kalangan masyarakat Kampung Dukuh terdapat kepercayaan tentang adanya hari baik dan hari buruk (nahas). Pengetahuan mengenai perhitungan tersebut diperoleh dari karuhun (nenek moyang) dan sekarang menjadi tradisi atau kebiasaan yang dilakukan oleh mereka. Penentuan hari baik dan hari buruk tersebut berkaitan dengan perhitunganperhitungan tentang waktu (kala). Kala terdiri dari kala alit (kala kecil) dan kala ageung (kala besar). Kala alit diperhitungkan berdasarkan tanggal Hijriah sedangkan kala ageung berdasarkan penanggalan Masehi. Berdasarkan perhitungan tersebut maka terdapat beberapa larangan atau pantangan, yakni dilarang melakukan kegiatan pada hari-hari tertentu di bulan-bulan tertentu (larangan sasih), seperti dilarang bepergian pada hari Sabtu dan Minggu pada bulan Muharam, Shafar, dan Maulud (Rabiul Awwal); hari Senin dan Selasa pada bulan Silih Maulud (Rabiul Akhir), Jumadil Awal, dan Jumadil Akhir; hari Rabu dan Kamis pada bulan Rajab, Rewah (Sya'ban), dan Ramadhan; dan hari Jum'at dan Sabtu pada bulan Syawal, Hapit (Dzulqa'dah), dan Rayagung (Dzulhijah).

Selain larangan sasih juga terdapat beberapa hari tertentu yang dianggap tabu untuk melakukan kegiatan 
tertentu, yaitu: tidak boleh membuat pagar pada hari Minggu; dilarang membuat rumah dan memasang pagar pada hari Rabu; dilarang bekerja di sawah, kebun atau pergi ke pasar dan menjual hasil pertanian pada hari Jum'at dan hari Selasa.

Di samping itu, terdapat aturan atau adat yang mengikat perilaku mereka dalam kehidupan sehari-hari, di antaranya: dilarang selonjoran (menjulurkan kaki) ke arah makam keramat; buang air ke arah barat, dan lain-lain. Sedangkan ritual yang telah menjadi tradisi di antaranya adalah ritual tilu waktos (tiga waktu), yaitu pada 1 Syawal, 10 Rayagung (Dzulhijah), 12 Maulud(Rabiul Awwal), dan 10 Muharam. Ritual ini khusus dilakukan oleh kuncen dengan membawa makanan ke dalam bumi alit atau bumi lebet (rumah kecil atau rumah dalam) dan kemudian melakukan "tawasul” serta berdoa.

Ritual Cebor Opat Puluh adalah ritual mandi dengan empat puluh kali siraman air dari pancuran yang dicampur dengan air khusus yang telah diberi doa-doa oleh kuncen. Ritual ini dipimpin oleh Lawang (wakil kuncen) dan dilakukan oleh mereka yang mempunyai maksud dan tujuan tertentu, seperti hendak melakasnakan Jaroh (ziarah), menjauhkan diri dari penyakit, kotoran dan dosa yang ada dalam tubuh. Air yang digunakan pada ritual berasal dari sumber mata air di Makom Karomah Syekh Abdul Jalil yang dialirkan melalui pancuran ke jamban umum.

Sedangkan ritual Jaroh (ziarah) merupakan bentuk ritual ziarah ke makam Syekh Abdul Jalil. Ritual ini dilakukan dengan didahului oleh ritual mandi Cebor Opat Puluh dan mengambil air wudhu serta menanggalkan semua perhiasan serta menggunakan pakaian yang tidak bercorak yang telah disediakan yaitu berbentuk "gamis" berwarna putih polos. Ritual ini dilaksanakan hanya pada hari Sabtu. 
Islam, Tradisi Lokal, dan Konservasi Alam:

\section{E. Konservasi Alam dan Keaneka-ragaman Hayati}

Di antara isu-isu global yang akhir-akhir ini mencuat dan menjadi pembicaraan baik di kalangan ahli lingkungan maupun para ilmuwan adalah masalah perubahan iklim (climate change) dan pemanasan global (global warming). Perubahan iklim yang diakibatkan oleh adanya pemanasan global telah memaksa masyarakat dunia sadar akan pentingnya memelihara lingkungan dan keaneka-ragaman hayati (biodiversity).

Sayangnya, hutan dan lingkungan alam sudah banyak yang rusak akibat perilaku manusia yang tidak bijak terhadap alam. Tuntutan konsumerisme dan juga perilaku ketergesaan manusia dalam memperoleh penghasilan adalah pemicu munculnya eksploitasi terhadap alam. Hutan hanya diambil kayunya dan lahan bekas hutan beralih fungsi menjadi perkebunan. Demi memenuhi atau keinginan hidup, manusia sudah banyak mengabaikan "etika-etika lingkungan" yang telah menjadi tradisi. Manusia sudah tidak lagi "hormat" pada alam yang dulu telah memberi kehidupan. Sikap hormat tersebut berupa pemanfaatan yang tidak serakah dan juga memberikan pada alam timbal balik yang "sesuai".

Sebagai masyarakat yang dianggap tradisional kearifan lokal yang dimiliki warga Kampung Dukuh sama dengan kearifan lokal yang dimiliki masyarakat adat lainnya. Mereka menyesuaikan hidup dengan irama alam di sekelilingnya dan mengonstruksi aturan-aturan berdasarkan pengalaman hidup mereka secara komunal. ${ }^{5}$ Mereka percaya bahwa alam di mana mereka tinggal adalah juga mahluk hidup yang dapat berinteraksi dengan manusia. Oleh karena itu, untuk dapat bertahan hidup maka selayaknya alam diperhatikan dan diajak berkomunikasi.

${ }^{5}$ Abdullah, dkk (eds.), Agama dan Kearifan Lokal dalam Tantangan Global, Yogyakarta, Sekolah Pascasarjana bekerja sama dengan Pustaka Pelajar, cet. 1, 2008, h. 5 . 
Aturan-aturan seperti adanya larangan-larangan tertentu (pamali) berkaitan dengan pengelolaan hutan, tanam-tanaman, mata air, gunung, sungai, rumah, alat-alat, dan lain-lain yang dikemas dengan mitos-mitos dan bermacam-macam upacara tradisi, yang dalam pandangan para ahli disebut sebagai kearifan lokal, adalah bentuk perwujudan dari interaksi dan komunikasi masyarakat adat dengan lingkungan alam di sekitarnya. Dengan kearifan lokal tersebut masyarakat adat, tak terkecuali warga Kampung Dukuh, dapat melestarikan sumber daya alam dengan berbagai keaneka-ragaman hayatinya. ${ }^{6}$

Dalam sebuah hasil penelitian yang pernah dilakukan oleh Endah Sulistyawati, ahli etnobotani dari ITB, dikatakan bahwa penduduk kampung Dukuh juga sangat menghargai sekaligus berguru pada alam sehingga mereka memiliki potensi pengetahuan yang besar tentang tumbuhan yang dapat dijadikan obat-obatan yang diambil dari bagian akar, batang, biji, buah, bunga, daun, rimpang maupun umbinya. Lebih lanjut dikatakan oleh Endah bahwa di Kampung Dukuh terdapat 137 jenis tumbuhan obat dan dari dari 137 jenis tumbuhan tersebut yang digunakan untuk pengobatan proporsi terbesar dimanfaatkan untuk perawatan kesehatan ibu melahirkan yaitu sebanyak 41 jenis tumbuhan. ${ }^{7}$ Dengan demikian dapat dikatakan bahwa penduduk Kampung Dukuh

${ }^{6}$ Haba menyatakan bahwa ada enam fungsi yang signifikan dari kearifan lokal: pertama, sebagai penanda identitas sebuah komunitas; kedua, elemen perekat (aspek kohesif) lintas warga, lintas agama dan kepercayaan; ketiga, kearifan lokal tidak bersifat memaksa atau dari atas (top down), tetapi unsur kultural yang ada dan hidup dalam masyarakat; keempat, kearifan lokal memberikan warna kebersamaan bagi sebuah komunitas; kelima, local wisdom mengubah pola pikir dan hubungan timbal balik individu dan kelompok, dengan meletakkannya di atas common ground/kebudayaan yang dimiliki; keenam, kearifan lokal dapat berfungsi mendorong terbangunnya kebersamaan (Abdullah,dkk (eds.), Agama dan Kearifan Lokal dalam Tantangan Global, Yogyakarta, Sekolah Pascasarjana bekerja sama dengan Pustaka Pelajar, cet. 1, 2008) Cetak. 1 h.7-8)

7 Sumber: http://www.docdatabase.net/more-etnobotani-tumbuhanobat-oleh-masyarakat-adat-kampung-986731.html (diunduh tgl 26/3/2014). 
Islam, Tradisi Lokal, dan Konservasi Alam:

tidak saja mampu memenuhi kebutuhan hidupnya tetapi juga telah turut andil dalam menyelamatkan dunia dengan melestarikan keaneka-ragaman hayati yang ada di sekitarnya.

Keberadaan hutan dan keaneka-ragaman hayati yang terdapat di dalamnya penting dalam menunjang kehidupan dan aktifitas manusia. Hutan tidak saja dipahami sebagai bagian dari ekosistem yang membantu kehidupan manusia melainkan juga merupakan bagian yang tak terpisahkan dari budaya masyarakat itu sendiri. Di dalam hutan tersimpan tidak saja keaneka-ragaman hayati (biodiversity) melainkan terdapat jejak-jejak sejarah yang menunggu dalam beku untuk diungkap misterinya.

Kawasan Hutan Larangan di Kampung Dukuh ini masih tetap lestari dan juga tidak mengalami perubahan fungsi dari zaman dahulu. Orang tidak diperbolehkan memasuki kawasan Hutan Larangan kecuali pada saat ziarah dan ada orang meninggal. Ziarahpun ditentukan hari dan waktunya, yaitu hari Sabtu pagi. Larangan ini tidak hanya berlaku bagi masyarakat setempat tetapi juga masyarakat umum.

Upaya menjaga suatu daerah untuk tetap lestari yang dilakukan oleh masyarakat akan dapat bertahan lama karena berangkat dari kesadaran masyarakat setempat. Menjaga kelestarian hutan berarti menjaga ekosistem yang di dalamnya terdapat bermacam-macam tumbuh-tumbuhan dan hewan. Itu sebabnya di Kampung Dukuh masih terdapat banyak jenis tanaman yang di tempat-tempat lainnya dianggap telah punah, seperti Lame hideung, Lame bodas, Koneng bodas, Koneng hideung, Koneng ageung, Kunci, Harendong, Jarong, Kingkilaban, Dahu, dan lain-lain.

\section{F. Wawasan Islam tentang Lingkungan Alam}

Tidak sedikit doktrin Islam yang berbicara tentang lingkungan hidup (biotik - abiotik) baik itu berkaitan dengan bumi atau tanah, air, tumbuh-tumbuhan, hewan, dan lain- 
lain. Dalam kaitan dengan kehidupan manusia di muka bumi, Islam tidak hanya menekankan pentingnya hubungan manusia dengan Allah SWT sebagai Tuhan Pencipta alam semesta dan manusia di dalamnya, tetapi juga menekankan pentingnya hubungan manusia dengan alam sekitar. Allah SWT telah menjadikan manusia sebagai khalifah di muka bumi (Q.S. 2: 30) dan menjadikan segala apa yang ada di bumi untuk manusia (Q.S. 2: 29). Ini berarti bahwa manusia memikul mandat untuk mengelola bumi beserta segenap isinya, suatu tugas atau pekerjaan yang tidak saja harus dilaksanakan dengan sungguhsungguh tetapi juga harus dipertanggung-jawabkan terhadap Tuhan sebagai Sang Pemberi mandat. Dengan kata lain, dalam mengelola bumi dan segala isinya tersebut manusia tidak boleh semena-mena, tetapi harus sesuai dengan kehendak dan aturan yang telah digariskan Allah SWT.

Al-Quran menyatakan bahwa Adam a.s. dan manusia diciptakan dari tanah (Q.S. 3: 59), kemudian mereka berkembang biak (Q.S. 30: 20). Manusia, hewan, tumbuhtumbuhan yang hidup di bumi tidak lepas dari tanah.

Air merupakan sumber kehidupan (Q.S. 21: 30) bagi semua makhluk hidup yang ada di muka bumi. Air membuat bumi yang kering menjadi subur (Q.S. 22: 5) sehingga negeri yang mati menjadi hidup kembali (Q.S. 43: 11). Allah SWT menurunkan air hujan sehingga tumbuh berbagai macam tanaman (Q.S. 20: 53) yang bermanfaat bagi manusia dan makhluk hidup lainnya (Q.S. 10: 24). Allah juga menumbuhkan butir tumbuhan dan biji buah-buahan (Q.S. 6: 95) sehingga menghijau, sedap dipandang mata (Q.S. 22: 5), berbunga, berbuah matang (Q.S. 6: 99) dan menjadi makanan ternak (Q.S. 16: 10) maupun manusia.

Binatang ternak diciptakan untuk manusia (Q.S. 6: 5) baik untuk dipekerjakan maupun untuk dimakan dan dinikmati dagingnya sebagai rizki dari Allah SWT (Q.S. 6: 142) atau diminum air susunya (Q.S. 16: 66). Begitu juga binatang 
buruan dan yang berasal dari laut adalah halal (Q.S. 5: 96) untuk dikonsumsi oleh manusia.

Berdasarkan kutipan ayat-ayat al-Quran di atas maka sudah seharusnya manusia merasa berkewajiban untuk menjaga, memelihara, dan melestarikan bumi dan segala apa yang ada di dalam maupun di atasnya. Akan tetapi, ulah manusia telah membuat berbagai kerusakan di muka bumi baik darat maupun di laut (Q.S. 30: 41), dan hanya orang-orang munafiklah yang membuat kerusakan baik terhadap tanaman maupun binatang ternak (Q.S. 2: 205).

Sebagai implementasi nilai-nilai al-Quran di atas Nabi Muhammad SAW sangat peduli terhadap lingkungan alam. Beliau mengajarkan bahwa kebersihan dan ketertiban merupakan bagian dari iman (H.R. Ad-Dailami); menganjurkan membuang duri dari jalan (H.R. Bukhari dan Thabrani); dan melarang buang air di jalan tempat orang lewat dan di tempattempat orang biasa berteduh (H.R. Muslim dan Abu Daud dari Abu Hurairah), Nabi SAW juga melarang buang air di tempat air tergenang (H.R. Muslim dari Jabir). ${ }^{8}$

Rasulullah SAW juga sangat besar kepeduliannya terhadap kelestarian alam. Beliau menyatakan bahwa menanam pohon merupakan sedekah yang pahalanya terus mengalir hingga hari kiamat (H.R. Abu Daud). Kepedulian beliau terhadap lingkungan dan sesama makhluk hidup ditunjukkan oleh pesannya yang diutarakan oleh Abu Bakar kepada Yazid bin Abu Sufyan yang hendak memimpin perang untuk tidak membunuh (merusak) bumi), tidak menghancurkan bangunan, tidak membunuh perempuan, tidak membunuh orang lanjut usia, tidak menebang atau membakar pohon yang sedang

${ }^{8}$ Mufid, Islam dan Ekologi Manusia, (Bandung: Nuansa, cetakan pertama, 2010), h. 275-6. 
berbuah, tidak membunuh hewan kambing atau unta kecuali untuk dimakan. ${ }^{9}$

\section{G. Islam di Kampung Dukuh}

Islam memperlihatkan pengaruhnya yang cukup kuat di kalangan masyarakat Sunda. Seperti orang-orang Melayu, terdapat upaya identifikasi jati diri Sunda dengan Islam, yaitu "Sunda adalah Islam dan Islam adalah Sunda". Hal ini tidak terjadi di kalangan masyarakat Jawa meskipun para wali penyebar agama Islam berasal dari etnis Jawa.

Hubungan erat antara Islam dengan Sunda juga tampak di kalangan masyarakat adat Sunda, seperti di Kampung Naga, Kampung Kuta, Kampung Pulo, Kampung Mahmud, Kampung Adat Ciptagelar, dan lain-lain. Mereka rata-rata adalah pemeluk agama Islam. Namun tingkat dan kualitas hubungan tersebut berbeda dari satu masyarakat dengan masyarakat adat yang lainnya. Masyarakat adat Ciptagelar, misalnya, mengaku beragama Islam. Meskipun demikian, pengaruh adat dan kebudayaan Sunda nampaknya lebih kuat dibandingkan dengan pengaruh agama Islam. Bahkan akhir-akhir ini terdapat tanda-tanda adanya gerakan kebangkitan kebudayaan Sunda di kalangan masyarakat Ciptagelar. ${ }^{10}$

Meskipun gerakan kebangkitan adat dan kebudayaan Sunda tidak begitu nampak di Kampung Kuta tetapi warna dan pengaruh agama Islam juga tidak begitu nampak di kalangan masyarakat adat Kampung Kuta. Baik di masyarakat adat Ciptagelar maupun di masyarakat adat Kampung Kuta keadaan masjid, misalnya, sama-sama dalam kondisi yang memprihatinkan. Sementara kondisi masjid di Ciptagelar

\footnotetext{
${ }^{9}$ Suryadi, 'Cageur Bageur Ngokola Lingkungan' dalam Muhtadi dan Agus Ahmad Safei (ed.), Al-Qur'an Kitab Ramah Lingkungan, (Bandung: LPTQ Provinsi Jawa Barat, cet. pertama, 2012), h. 154.

${ }^{10}$ Bandingkan, Mulder, Kebatinan dan Hidup Sehari-hari Orang Jawa (Kelangsungan dan Perubahan Kulturil), terj. Alois A. Nugroho, (Jakarta: Gramedia, 1983), hlm 10-11.
} 
Islam, Tradisi Lokal, dan Konservasi Alam:

sangat kotor, terlantar dan tidak terurus, fasilitas untuk mengambil air wudhu di masjid Kampung Kuta terlihat rusak parah, tidak terpelihara, dan memperlihatkan tidak banyak digunakan orang.

Barangkali hal ini bisa dimaklumi karena, tidak seperti asal-usul masyarakat adat Kampung Dukuh, asalusul masyarakat adat Kampung Kuta maupun Ciptagelar bukanlah tokoh penyebar agama Islam. Meskipun demikian, patut diperhatikan bahwa masyarakat adat Kampung Pulo di Kecamatan Leles Kabupaten Garut pun yang asal-usulnya adalah seorang tokoh yang dipercaya sebagai penyebar agama Islam di daerah Garut, yakni Arif Muhammad, tidak memperlihatkan bahwa keturunannya mewarisi ghirah ke-Islam-an yang cukup kuat. Hal ini dapat dilihat pada kondisi masjid, tepatnya surau/mushola, yang selain kecil juga hanya menjadi penghias kompleks perkampungan adat Kampung Pulo. Masjid atau mushola di Kampung Pulo hanya disinggahi oleh pengunjung yang mencukupkan diri mengambil air wudhu dengan air seadanya dan di tempat yang agak terbuka.

Asal-usul masyarakat adat Kampung Naga bukanlah seorang kiyai atau tokoh penyebar agama Islam, tetapi praktik keagamaan nampaknya tidak ketinggalan dan bukan sesuatu yang asing. Tanpa kumandang adzan melalui speaker, tetapi melalui pukulan bedug besar, masyarakat adat Kampung Naga menggunakan masjid baik untuk ritual keagamaan maupun untuk upacara adat. Meskipun agak terbuka tetapi fasilitas air wudhu tersedia cukup besar. Namun, tidak seperti di Kampung Dukuh, di Kampung Naga tidak ada kegiatan pesantren dan pengajian, sesuatu yang menjadi ciri khas di Kampung Dukuh. Berdasarkan informasi yang didapat adanya kegiatan pengajian dan santri mondok di Kampung Dukuh karena kuncen Kampung Dukuh sendiri adalah santri yang pernah belajar di beberapa pesantren. 
Dengan demikian dapat dikatakan bahwa Kampung Dukuh merupakan kampung adat yang ada di kalangan masyarakat Sunda dengan tradisi ke-Islam-an yang cukup kuat dibandingkan dengan kampung-kampung adat Sunda lainnya.

Memang, dalam hal ke-Islam-an masyarakat Kampung Dukuh berbeda dengan kebanyakan masyarakat adat lainnya. Dapat dikatakan bahwa, dibandingkan dengan masyarakat adat yang lain, warga Kampung Dukuh masih memegang dan memelihara tradisi Islam. Sebagai keturunan langsung atau tak langsung Syekh Abdul Jalil mereka menganggap Syekh Abdul Jalil adalah seorang "wali". "Wali" adalah sebuah gelar yang dikenakan kepada mereka yang telah mencapai tingkat spiritual yang tinggi dan patut diteladani. Hal ini berbeda dengan masyarakat adat Kampung Pulo di Kecamatan Leles Kabupaten Garut. Meskipun warga Kampung Pulo menganggap bahwa dirinya sebagai keturunan Arif Muhammad dan bahwa Arif Muhammad dianggap sebagai tokoh penyebar agama Islam di daerah tersebut, tetapi warga Kampung Pulo lebih suka menyebut Arif Muhammad dengan sebutan "Eyang", sebuah gelar tradisional yang dinisbahkan kepada mereka yang dianggap sebagai leluhur dan asal-usul keturunan selanjutnya. Dengan kata lain, "Eyang” lebih bersifat biologis.

Selain itu, sebagaimana dinyatakan oleh kuncen Kampung Dukuh, Mama Uluk, dan beberapa warga lainnya, bahwa warga Kampung Dukuh menganut mazhab (aliran) Imam Syafi'i dan mengikuti ajaran tasawuf yang menganjurkan hidup sederhana. Jelas ini mengindikasikan bahwa masyarakat Kampung Dukuh memiliki keterkaitan erat dengan tradisi Islam di mana dalam Islam terdapat empat aliran fiqih (Imam Hanafi, Imam Hambali, Imam Maliki, dan Imam Syafi'i). Keterkaitan ini terlihat dalam bentuk di mana berbagai aktifitas keagamaan dapat disaksikan, seperti shalat berjamaah tepat pada waktunya, kegiatan pengajian baik untuk ibu-ibu maupun bapak-bapak, berkerudung menutup aurat terutama 
Islam, Tradisi Lokal, dan Konservasi Alam:

kaum perempuan, penyelenggaraan pendidikan bagi anakanak di madrasah, bercita-cita menunaikan ibadah haji, dan lain-lain.

Dengan kata lain, Islam di kalangan masyarakat Kampung Dukuh tidak lagi berada pada ranah pribadi, tetapi telah menembus ranah domestik dan bahkan publik. Di antara para pengunjung, misalnya, terdapat beberapa orang yang berasal dari daerah lain di luar Kabupaten Garut. Mereka sengaja datang dan mondok menjadi santri untuk menimba ilmu tasawuf dari kuncen Kampung Dukuh.

Meskipun demikian, dengan memperhatikan perilaku, aktifitas, dan perbincangan yang dilakukan memberikan gambaran bahwa wawasan agama Islam, yang membedakan identitas Kampung Dukuh dengan Kampung-kampung Adat lainnya, tidak menjadi inspirasi bagi kegiatan mereka dalam mengelola lingkungan alam di sekitar mereka. Pelajaran agama dan ceramah-ceramah keagamaan yang disampaikan kepada anak-anak maupun ibu-ibu pengajian lebih berorientasi kepada hukum-hukum fiqih ibadah (ubudiyah) dalam konteks ibadah mahdhoh. Penekanan kepada pengamalan ibadah dengan orientasi mendapatkan pahala di akhirat sangat dominan dalam penyampaian pelajaran agama di madrasah maupun dalam ceramah-ceramah dan khutbah Jumat di Masjid.

Selain dalam ibadah mahdhoh (vertikal) doktrin agama Islam yang sering mendapat penekanan adalah doktrindoktrin yang berkaitan dengan hubungan sosial (horizontal). Dengan kata lain, di samping menekankan harapan terhadap pahala dari pelaksanaan ibadah terhadap Tuhan pengajaran dan dakwah Islam ditekankan pada nilai-nilai etika dalam konteks hubungan sosial dengan sesama warga maupun dengan orang lain.

Di sisi lain, aktifitas untuk tidak menebang pohon atau merusak Hutan Keramat atau memelihara mata air yang menjadi sumber kehidupan tidak disandarkan kepada motivasi 
adanya perintah ayat-ayat suci atau anjuran-anjuran agama. Sebaliknya, upaya-upaya tersebut lebih disandarkan kepada adanya larangan adat yang telah disampaikan dari generasi ke generasi. Dapat dikatakan bahwa mereka tidak melakukan perusakan terhadap pohon-pohonan di Hutan Keramat dan sumber mata air karena mereka lebih takut terhadap kutukan leluhur (kwalat) dari pada terhadap larangan Tuhan.

\section{H. Penutup}

Dalam menghadapi isu global adanya perubahan iklim (climate change) yang disebabkan oleh terjadinya pemanasan global (global warming) yang mengancam kehidupan umat manusia masyarakat dituntut untuk memperhatikan kembali tentang alam lingkungan, baik bumi (tanah), air, hutan, udara, dan lain sebagainya. Umat Islam, dengan seperangkat doktrin yang diyakini, selayaknya memberikan respon terhadap persoalan lingkungan alam tersebut sebagai bagian dari proses ibadah yang menjadi kewajibannya.

Di lain pihak, masyarakat Kampung Adat dianggap telah mampu memberikan respon terhadap masalah perubahan iklim (climate change) dan pemanasan global (global warming) karena telah berhasil melakukan pelestarian dan konservasi alam. Di antara Kampung-kampung Adat maka Kampung Adat Dukuh merupakan Kampung Adat yang bukan hanya hidup berdasarkan kepada adat atau tradisi nenek moyang tetapi juga berpegang teguh kepada ajaran agama Islam. Dalam beberapa hal, tradisi Islam masih hidup dan dipelihara di kalangan masyarakat Kampung Dukuh.

Akan tetapi, pemahaman dan aktifitas keagamaan Islam tersebut tidak atau belum menyentuh aktifitas sosial berkaitan dengan pemeliharaan lingkungan alam sekitar. Konservasi alam di Kampung Dukuh lebih diakibatkan, sebagaimana masyarakat adat lainnya, oleh kepercayaan terhadap mitos-mitos dan praktik-praktik tradisi lokal dari 
Islam, Tradisi Lokal, dan Konservasi Alam:

pada disandarkan kepada alasan-alasan agama. Pernyataan bahwa warga Kampung Dukuh mengikuti mazhab atau aliran Syafi'i yang diwujudkan dalam bentuk praktik keagamaan pada ranah domestik dan publik di rumah-rumah, masjid, dan pesantren memberikan indikasi bahwa Islam dipahami oleh warga Kampung Dukuh dalam pengertian fiqih ibadah dalam arti yang sempit. Bahkan, santri-santri yang mondok untuk mempelajari tasawuf pun nampaknya cenderung tertarik untuk menimba ilmu kanuragan (kekebalan fisik). Hal ini terlihat dengan adanya pertunjukan debus yang menjadi tontonan pada acara khitanan atau acara-acara lainnya. [] 


\section{DAFTAR PUSTAKA}

Abdullah, Irwan, Konstruksi dan Reproduksi Kebudayaan, Yogyakarta, Pustaka Pelajar, 2006. , dkk (ed.), Agama dan Kearifan Lokal dalam

Tantangan Global, Yogyakarta, Sekolah Pascasarjana UGM bekerja sama dengan Pustaka Pelajar, cet. 1, 2008.

Cunningham, A.B., Applied Ethnobotany: People, Wild Plant Use and Conservation.WWF, UNESCO, Kiew Royal Botanic Garden, Earthscan Publication, 2001.

Dove, M,R., Indigenous People and Environmental Politics, Annual Review of Anthropology, 2006.

Ekadjati, Edi S., Kebudayaan Sunda Suatu Pendekatan Sejarah, Bandung: Pustaka Jaya, 1995.

Iskandar, Johan, Manusia Budaya dan Lingkungan: Ekologi Manusia, Bandung, Humaniora Utama Press, 2001.

Makmur, Ade (ed.), Buku Kearifan Lokal di tengah Modernisasi, Jakarta: Kementerian Kebudayaan dan Pariwisata RI, 2011,

Mufid, Sofyan Anwar, Islam danEkologiManusia, Bandung: Nuansa, cet. 1, 2010.

Muhtadi, Asep S. danAgus Ahmad Safei (ed.), Al-Qur'an Kitab Ramah Lingkungan, Bandung: LPTQ ProvinsiJawa Barat, cet. pertama, 2012.

Al-Qur'an KitabKehidupan, Bandung, LPTQ ProvinsiJawa Barat, cet. pertama, 2004.

Mulder, Niels, Kebatinan dan Hidup Sehari-hari Orang Jawa (Kelangsungan dan Perubahan Kulturil), terj. Alois A. Nugroho, Jakarta, Gramedia, 1983.

Soedjito, H. Dan Endang sukara, "Mengilmiahkan Pengetahuan Tradisional: Sumber Ilmu Masa Depan Indonesia" dalam 
Islam, Tradisi Lokal, dan Konservasi Alam:

Kearifan Tradisional dan Cagar Biosfer di Indonesia, Jakarta: LIPI dan Komite Nasional Man and The Biosphere Indonesia, 2006.

Syukur, Abdul, 'Islam, Etnisitas dan Politik Identitas: Kasus Sunda', dalam Miqot (Jurnal Пlmu-ilmu Keislaman), vol. XXXV No 2 Juli-Desember 2011. , 'Kampung Kuta: Sebuah Dunia Tanpa Perniagaan' dalam Zerorisk, vol. 07, September-Oktober 2013.

Tanjov, Yulia Estmirar, dkk., KampungDukuhdanAdat-Istiadatnya sebagai Daya Tarik Wisata Budaya di Kabupaten Garut, Bandung, Laporan Perjalanan, Fakultas Perikanan dan Ilmu Kelautan Parimanta, Universitas Padjadjaran, 2011.

http://www.docdatabase.net/more-etnobotani-tumbuhan-obatoleh-masyarakat-adat-kampung-986731.html

http://curiousyuwie.blogspot.com/2012/12/yulutrip.blogspot. com.html

http://limbangangarut.com/article/39453/agama-islam-dalamperkem bangan-budaya-sunda-oleh-prof-dr-h-dadangkahmad-msi.html. 
